\title{
On graphic memory as a strategy for design history
}

The expression 'memória gráfica' (literally, 'graphic memory') has been used in Portuguese and Spanish-speaking countries in Latin America, more and more frequently, in the last years, in order to refer to a line of studies that intends to review the significance and value of visual artifacts, and in particular of printed ephemera, in the establishment of a sense of local identity through design.

This paper intends to review the contexts in which this expression has been used within the field of research on visual artifacts in Latin America, and to discuss the relationships between the concept of 'graphic memory' and those of 'print culture,' 'visual culture,' and 'material culture,' setting up a proposal of how it can be applied as an approach to the history of graphic design in non-hegemonic countries. visual design, design history methods, Latin America, $21^{\text {st }}$ century

\section{Introduction}

If we look for the expression 'graphic memory' in Internet search engines like Google or even Google Scholar, most of the links found will be about computer devices or systems dedicated to the storage of data related to images. The same happens if we use the expression 'memoire graphique', in French. If we use the expression 'memoria grafica' however, we will find a significant number of links related to research on graphic design history and photographic archives, most of them in Portuguese or Spanish.'

That reflects a trend, that can be traced back to the early $21^{\text {st }}$ century, of using this expression to describe efforts to rescue or to re-evaluate visual artifacts, in particular printed ephemera, aiming at the recovery or the establishment of a sense of local identity. Such efforts are somehow related to the assumption that those artifacts would be examples of what Assmann (1995) describes as objectified cultural memory, concrete carriers of 'mnemonic energy', able to store knowledge from which a group would derive "an awareness of its unity and peculiarity" (Assmann 1995: 130).

Although seminal contributions to the studies on the relationship between memory, history and culture date back to the early $20^{\text {th }}$ century (Halbwachs 1925,1950 ) and early

\footnotetext{
'While the sequence of characters is exactly the same for writing memoria grafica in Portuguese, Spanish, and also Italian, there are slight differences in orthography due to the use of diacritics in the first two idioms (acute accents over ' $o$ ' and the second ' $a$ ' in Portuguese, and only over the second ' $a$ ' in Spanish). I will therefore use the expression without diacritics to refer to the use of this expression in both Portuguese and Spanish.
} 
1980's (Nora 1984), it is only in the late 1980's and 1990's, according to Sturken (2008), that the studies on memory emerged as a field of inquiry. Studies on memoria grafica, by their turn, are more numerous and consistent since 2008. In Brazil, this coincides with the start of a research project joining universities from São Paulo, Rio de Janeiro and Pernambuco, and the launching of related a website, both named Memória Gráfica Brasileira (Brazilian graphic memory).

Graphic artifacts play an important role in everyday life, through our communication and exchange experiences and in our interactions with the urban landscape. Despite their importance for the constitution of a visual culture that contributes to the formulation of collective identities, studies on the configuration of such artifacts, in particular before the establishment of the academic and professional field of design, and specially in countries that imported design traditions from abroad, have been neglected for many decades.

It is clear, therefore, that 'graphic memory' shares interests and methods with betterknown fields of studies, such as visual culture, print culture and material culture, and those shared aspects will be used to guide the brief survey that follows. I will conclude with a reflection on how the studies on 'graphic memory' are helping in the construction of local histories of design in Latin America.

\section{Graphic memory and visual culture}

An important number of studies described by their authors as memoria grafica are collections of images, accompanied by some kind of description or analysis. Within this group, we must differentiate the use of memoria grafica, mostly found in Spanish, to describe a collection of drafts, or of images that served only as a reference for a project, but are not central to it, to the use of the same expression in the sense explored in this paper.

Examples of the former are the blog Memoria Gráfica de Honduras, a collection of old photos set up in 2009, ${ }^{2}$ and the declaration by Brazilian fashion designer Ronaldo Fraga, given during a recent interview, that he always keeps a 'graphic memory' of his collections. ${ }^{3}$ That does not exclude, however, that those collections of images may serve a starting point for the systematic descriptions and critical analysis that characterize studies in the fields of graphic memory and visual culture.

Collecting images, and organizing them, sometimes as sophisticated digital databases, is a necessary step for most research projects on memoria grafica. An early example of this is the graduation project Memoria Gráfica de la Historia del Pulque en México (Salazar Dreja 2004), where the author collected, produced and organized data (including old and new photographs, drawings and information obtained from bibliographic research and interviews) aiming to a comprehensive record of the visual culture associated with the Mexican beverage known as pulque, and the traditional places were it used to be sold and consumed (pulquerias).

The website J. Carlos em Revista4, associated with the Memória Gráfica Brasileira initiative, is an example of a sophisticated and comprehensive database containing

\footnotetext{
${ }^{2}<$ fotosantiguashonduras.blogspot.com $>$

${ }^{3}<$ http://glamurama.uol.com.br/ronaldo-fraga-confessa-desenho-e-anoto-tudo-por-panico-de-perdera-memoria/>

${ }^{4}<$ http://www.jotacarlos.org/>
} 
digitized versions of dozens of issues of the magazines Para Todos and O Malho, designed by illustrator J. Carlos in the 1920's. Although the website contains only the database, two books were published by the coordinators of the project, analyzing aspects of the collection.

Other examples of studies on graphic memory related to visual culture, this time with a focus on national identity are a graduation project about the graphic symbols used for the city of Cuenca, in Ecuador (Pesántez Jara 2012), and, in a more politically engaged tone, two books on graphics (mostly posters) from the years of exile and resistance during the military regime in Chile and Brazil (Aguirre Argomedo \& Chamorro Martínez 2008, Sacchetta 2012).

Recurrent topics of interest for memoria grafica studies are vernacular or popular graphics. Examples of this are 'La Memoria Canalla de Bogotá', a paper presented in a conference in Spain, about an exhibition of street art in Colombia (Canales Hidalgo 2011), and the investigations on popular lettering and printed ephemera in the Brazilian cities of Recife, Rio de Janeiro and São Paulo conducted in the context of the research project Memória Gráfica Brasileira (Farias, Finizola \& Coutinho 2010; Farias \& Coutinho forthcoming).

Studies on graphic memory and visual culture share an interest in understanding the way in which society selects or creates images and visual forms, and, at the same time, is in some sense reflected in such images and forms. However, while the field of visual culture is mostly concerned with the aspects of visual artifacts that are perceived through vision (Duncum 2001: 106, Mirzoeff 2012: 5-6,), researchers working with memoria grafica, in particular those with a background in graphic design, are very often interested in the technical aspects involved in the production of such artifacts. In this aspect, graphic memory shares concerns and methods with the field of studies known as 'print culture.'

\section{Graphic memory and print culture}

The pioneers of the field of studies know as 'print culture' defined it in contrast to 'scribal' (Eisenstein 1980), 'oral' or 'chirographic' (Ong 1982) cultures. The advent of print culture is usually described as connected to the advent of printing books with movable type in fifteenth century Europe. Ong even uses the expression 'typographic culture' (Ong 1982: 42) as a synonym of 'print culture.'

Although we can find a number of studies on the origins of printing with movable type in Latin America under the umbrella of 'graphic memory' studies, the focus is usually not in the printing of books. The reason for this is that in countries like Brazil, for many years after the (very late) introduction of printing with movable types, most of the books in circulation continued to be imported from Europe, while Brazilian presses would produce

\footnotetext{
${ }^{5}$ Ghent, Design Museum Gent, Museum Archives, unnumbered: Proces-Verbaal van de 10de vergadering der werkgroep voor de studie van de Industriële Vormgeving, gehouden in het Instituut voor Industriële Vormgeving op 7 december 1960.

${ }^{6}$ The proliferation of Design Centres was a worldwide phenomenon. The Brussels Design Centre had one of the longest track records among such centers (22 years) and was established after the model of the British Design Centre in London. The Greek, New Zealand, Norwegian cases show similarities with the Belgian case. All are established out of commercial or economic reasons and present industrial design as an economic matter. See (Woodham 2010; Yagou 2005; Thompson 2011; Fallan 2007)
} 
mostly leaflets, newspapers and commercial almanacs.

Some examples of this kind of studies are the investigations on Brazilian nineteenth century or early twentieth century type specimens and almanacs conducted by members of the research teams responsible for the projects Memoria Gráfica Brasileira (Farias, Aragão \& Cunha Lima 2012, Farias \& Aragão forthcoming) and Memória Gráfica de Pelotas (Leschko 2010). The former inspired the latter initiative, established by researchers with backgrounds in design, semiotics and history, from the Federal University of Pelotas, a small town in the south of Brazil. A similar case is the research group Nigrafica, established by design researchers in the Federal University of Espirito Santo, in the South-Eastern coast of Brazil.

Studies on memoria grafica related to the circulation, production and reception of printed matter are not restricted to printing with movable type, however, including investigations on local traditions of lithographic printing (an example of which is to be found in Cunha Lima \& Lacerda 2013), and photocopied fanzines (Farias 2011). We can say, therefore, that this field of studies points to a wider understanding of what is the scope of 'print culture'.

\section{Graphic memory and material culture}

The term grafico/a, in Portuguese and Spanish, is strongly connected to printing. Not unlike the term 'graphic' in English, though, it also relates to visual representations. In both senses, it is associated to material qualities of objects: printed matter is not just visual, and tridimensional objects always convey visual information.

Graphic memory studies, in this aspect, overlaps with topics and methodological approaches from material culture studies. Some examples of this are a research on the patterns of old ornamented grilles found on houses in Belo Horizonte (capital city of Minas Gerais state, in Brazil, Goulart 2011), and another on the patterns traditionally used by a community of artisans in Ecuador (Erráez Cruz 2011).

While studies on cultural or collective memory focus on the recovery of personal accounts, having interviews and oral history as privileged methods, studies on graphic memory will very often focus on artifacts produced beyond the life-span of living testimonies, requiring procedures to derive 'history from things', like the ones exemplified by Lubar and Kingery (1993). The key method for deriving history from 'graphic things' is graphic and visual language analysis, which can tell us about repertoires, trends, tastes, and its circulation. Combined with systematic observations about the means and techniques of production of graphic artifacts, and with an understanding of the meanings attributed to them by clients, producers, and consumers, such analysis can afford rich historical interpretations.

\section{Conclusion}

Under the label memoria grafica, a significant number of studies have been conducted in the last 10 years. Such studies resulted in collections of visual data, including open-access digital databases, which allowed for descriptions and critical analysis, contributing to a better understanding of design traditions in Latin America. Such studies tend to highlight the peculiarities of the visual aspects of graphic artifacts, allowing for a sense of local tastes and identities. 
Most of the artifacts chosen as a theme for those studies are popular, commercial or vernacular items, produced by anonymous people, in many cases derivative, usually seen as commonplace and of low status. Artifacts like these have always been denied a place in European-centric, modernist design histories inaugurated by the import of Ulm and Bauhaus models for design education in the 1960's. By taking a distance from traditional art history methods, that tend to focus on outstanding authors and their exceptional and innovative works, studies on memoria grafica allows for an unbiased approach to print and visual culture of the local past, showing that its products can be exciting and empowering research topics.

The brief survey provided here demonstrates that research on 'graphic memory', as it has been conducted in Portuguese and Spanish speaking Latin America since the early twentieth century, has significant relations with better established research fields like visual culture, print culture and material culture. Further investigations may highlight connections with other related fields, like photographic memory. Understanding those relations is a first step towards identifying useful research tools from those fields, and also of recognizing the peculiarities of the memoria grafica approach.

Hopefully, this will inspire further research on 'graphic memory', not only in Latin America, but also in all countries so far excluded from the dominant narratives of design history.

\section{Acknowledgements}

I would like to acknowledge the financial support received from Brazilian research funding agencies CAPES, CNPq and FAPESP.

\section{References}

Aguirre Argomedo, E. \& Chamorro Martínez, S. (orgs.) (2008) "L": memoria gráfica del exilio chileno 1973-1989. Santiago: Ocho Libros.

Assmann, J. (1995) 'Collective memory and cultural identity', New German Critique, no. 65, Spring - Summer, pp. 125-133.

Canales Hidalgo, J. A. (2011) 'La Memoria Canalla de Bogotá', in: Buendía, L. A. (org.)

Ciudades (im) propias: la tensión entre lo global y lo local (Proceedings of II Congreso Internacional Arte y Entorno. Ciudades globales, espacios locales), Valencia: Centro de Investigación Arte y Entorno, pp. 233-240.

Cunha Lima, E. L. C. \& Lacerda, L. M. A. (2013) 'Pietro Biancovilli, o pioneiro da litografia comercial em Minas Gerais', Estudos em Design, vol. 21, no. 2, pp. 01-19.

Duncum, P. (2001) 'Visual culture: developments, definitions, and directions for art education', Studies in Art Education, vol. 42, no. 2, Winter, pp. 101-112.

Eisenstein, E.L. (1980) 'The emergence of print culture in the West', Journal of

Communication, vol. 30, no.1, pp. 99-106.

Erráez Cruz, D. (2011) Estrategias Visuales Creativas de Diseño Publicitario con motivos de la Memoria Gráfica de la Comunidad de Artesanos Saraguro, Graduation project, Universidad Tecnológica America, Quito, Ecuador.

Farias, P. L. (2011) 'Sem futuro: the graphic language of São Paulo city punk', in: Design History Society Annual Conference 2011: Design Activism and Social Change. Barcelona: Fundació Història del Disseny, pp. 1-16.

Farias, P. L. \& Coutinho, S. G. (forthcoming) 'Females, alcohol, and inebriating things: representations of women in cachaça labels', in: Proceedings of the 5T Conference 2013: Gendered Perspectives in Design, Izmir: Yașar University, pp. 69-70. 
Farias, P. L. \& Aragão, I. R. (forthcoming) 'Typography in Brazil in the 19th and early 20 th century: a history told from Brazilian type specimens', in: Proceedings of the Design History Society Annual Conference: Towards Global Histories of Design: Postcolonial Perspectives. Ahmedabad: National Institute of Design

Farias, P. L., Aragão, I. R. \& Cunha Lima, E. L. (2012) 'Unraveling aspects of Brazilian design history through the study of 19th century almanacs and type specimens', in: Conference

Proceedings: Design Research Society 2012, vol. 2, Bangkok: Chulalongkorn University, pp. 498-511.

Farias, P. L., Finizola, M. F. S. \& Coutinho, S. G. (2010) 'From the streets to the screen: street signs as a source of inspiration for digital typefaces', in: Gimeno-Martinez, J \& Flore, F. (eds.) Design and craft: a history of convergences and divergences. Brussel: Koninklijke Vlaamse Academie van Belgie, pp. 302-306.

Goulart, F. (2011) Grades de ferro ornamentais em Belo Horizonte: permanência e mobilidade na constituição de uma memória gráfica, in: Anais do 9 o Seminário docomomo Brasil. Brasília: UnB-FAU.

Halbwachs, M. (1925) Les cadres sociaux de la mémoire, Paris: Librairie Félix Alcan. (1950) La mémoire collective, Paris: Presses Universitaires de France.

Leschko, N. M. (2010) Tradição gráfica em Pelotas: Estudo de mapeamento da indústria gráfica com base nos anúncios publicados no Álbum de Pelotas 1922 e Almanach de Pelotas 1920-1929, in: Anais do $4^{\circ}$ Seminário Internacional em Memória e Patrimônio. Pelotas: UFPEL, pp. 618-631.

Lubar, S. \& Kingery, W. D. (orgs.) (1993) History from things: essays on material culture, Washington: Smithsonian Institution Press.

Mirzoeff, N. (2012) 'The subject of visual culture', in The Visual Culture Reader, London: Routledge, pp. 3-23.

Nora, P. (1984). 'Entre mémoire et histoire', in Les lieux de mémoire 1, Paris: Gallimard, pp. $23-43$.

Ong, W. (1982) Orality and literacy: the technologizing of the word, London: Methuen. Pesántez Jara, N. (2012) Memoria gráfica enfocada al análisis de los isologotipos del ilustre municipio en los últimos 20 años y sus aplicaciones, en base a los fundamentos del diseño. Graduation project, Engineering in Graphic Design, Universidad Tecnológica Israel, Cuenca, Ecuador.

Sacchetta, V. (org.) (2012) Os cartazes desta história: memória gráfica da resistência à ditadura militar e da redemocratização (19641985), São Paulo: Escrituras.

Salazar Dreja, O. C. (2004) Memoria gráfica de la historia del pulque en México, Graduation project, Department of Graphic Design, School of Arts and Humanities, Universidad de las Américas, Puebla, Mexico.

Sturken, M. (2008) 'Memory, consumerism and media: Reflections on the emergence of the field', Memory Studies, vol. 1, no. 1, January, pp. 73-78. 